\title{
Pengaruh Problem Based Learning Terhadap Kemampuan Pemecahan Masalah dan Self Efficacy Siswa Kelas VIII SMP Negeri 1 Patikraja
}

\author{
Destio Tabah Sujarwo \\ SMK Diponegoro Purwokerto \\ destio@gmail.com
}

\begin{abstract}
ABSTRAK
Penelitian ini bertujuan untuk mengetahui; apakah capaian kemampuan pemecahan masalah yang mengikuti Problem Based Learning lebih baik dari pada capaian kemampuan pemecahan masalah yang mengikuti pembelajaran langsung; apakah capaian self-efficacy yang mengikuti Problem Based Learning lebih baik dari pada capaian self-efficacy yang mengikuti pembelajaran langsung. Penelitian ini merupakan penelitian kuantitatif dengan metode eksperimen menggunakan metode Post-Test Only Control Design. Populasi dalam penelitian ini adalah seluruh siswa kelas VIII SMP Negeri 1 Patikraja. Pengambilan sampel menggunakan cluster random sampling dengan mengambil dua kelas yaitu kelas VIII F menggunakan Problem Based Learning dan kelas VIII D menggunakan pembelajaran langsung. Analisis data menggunakan Independent Sample t-Test untuk uji satu pihak kanan pada post test dan angket dengan $\alpha=0,05$. Diperoleh nilai signifikan kemampuan pemecahan masalah sebesar 0,031 dan self-efficacy sebesar 0,038. Kedua nilai signifikan tersebut kurang dari 0,05. Kesimpulan dalam penelitian ini adalah Problem Based Learning berpengaruh terhadap kemampuan pemecahan masalah dan self efficacy siswa.
\end{abstract}

Kata kunci: Problem Based Learning, kemampuan pemecahan masalah, self efficacy

\section{ABSTRACT}

This study aims to determine; whether the achievement of problem solving abilities that follow Problem Based Learning is better than the achievement of problem solving abilities that follow direct learning; whether the achievement of self-efficacy that follows Problem Based Learning is better than the achievement of self-efficacy that follows direct learning. This research is a quantitative study with an experimental method using the PostTest Only Control Design method. The population in this study were all students of class VIII SMP Negeri 1 Patikraja. Sampling using cluster random sampling by taking two classes, namely class VIII F using Problem Based Learning and class VIII D using direct learning. Data analysis using Independent Sample t-Test for onesided test right on the post test and questionnaire with $\alpha=0.05$. Obtained a significant value of problem solving ability of 0.031 and self-efficacy of 0.038. Both significant values are less than 0.05. The conclusion in this study is Problem Based Learning affect the ability of problem solving and self-efficacy of students.

Keywords: Problem Based Learning, problem solving skills, self efficacy

\section{Pendahuluan}

Pembelajaran matematika dapat dilakukan menggunakan berbagai model pembelajaran salah satunya adalah menggunakan model pembelajaran berbasis masalah. Kek dan Huijser (2017: 34) Problem Based Learning itu baik untuk mengajar pada abad ke 21, karena didalamnya memuat keterlibatan siswa dalam pembelajaran seperti siswa harus memahami masalahnya terlebih dahulu untuk mencari solusi dari permasalahan tersebut, kemudian siswa menyajikan jawaban dari permasalahan tersebut dan siswa dapat mengembangkannya, ketrampilan seperti itulah yang dibutuhkan pada abad ke 21, karena siswa dapat dengan mudah mendapatkan semua informasi kemudian siswa memahami informasi tersebut dan informasi itu dapat digunakan lagi untuk menciptakan karya dengan kekreatifan siswa.

Menurut Akinoglu (2007: 72) Problem Based Learning atau PBL akan menjadikan siswa dari menerima informasi pasif menjadi aktif (student centered), model ini memungkinkan siswa untuk memperoleh pengetahuan baru dalam pemecahan masalah, dalam problem based 
learning sikap siswa seperti pemecahan masalah, berpikir, bekerja kelompok, komunikasi dan informasi berkembang secara positif.

Secara umum pemecahan masalah matematis merupakan upaya yang dilakukan siswa untuk mencari jalan keluar terhadap kesulitan belajar matematika yang dihadapi. Hal-hal yang dibutuhkan oleh siswa dalam pemecahan masalah matematis yaitu memahami masalah, merencanakan penyelesaian, melaksanakan rencana penyelesaian dan memeriksa kembali hasil yang diperoleh. Dalam kurikulum 2013 fokus pembelajarannya tidak hanya memfokuskan pada pengetahuannya saja, namun sikap juga merupakan perhatian penting, salah satu sikapnya adalah self-efficacy. self-efficacy dapat diartikan suatu sikap menilai atau mempertimbangkan diri sendiri dalam menyelesaikan tugas yang spesifik. Maddux (1995) Self-efficacy pada awalnya didefinisikan sebagai jenis ekspektasi yang agak spesifik dengan keyakinan seseorang dalam kemampuannya untuk melakukan perilaku atau menentukan perilaku yang diperlukan untuk menghasilkan suatu hasil.

Namun dalam sebuah proses pembelajaran, self-efficacy menjadi suatu hal yang kurang menjadi suatu perhatian guru. Hal ini sejalan dengan pendapat Moma (2014: 435) guru matematika Sekolah Menengah Pertama (SMP) jarang memberi perhatian yang proposional untuk meningkatan selfefficacy matematis siswa. Keberhasilan tujuan pembelajaran hanya diukur dari tes hasil kemampuan siswa saja tanpa memperhatikan self-efficacy siswa.

Akibat dari hal tersebut, siswa kurang mengembangkan self-efficacy yang dimiliki sehingga self-efficacy siswa menjadi rendah. Siswa dengan selfefficacy yang rendah beranggapan bahwa mereka tidak memiliki kemampuan yang cukup untuk mengatasi kesulitan kesulitan yang ditemuinya dalam menjawab soal soal terutama yang berkaitan dengan pemecahan mesalah.

Seiring berjalannya waktu, sebagian besar guru menyatakan preferensi mereka untuk mengajar adalah menggunakan PBL dibandingkan dengan model tradisional dalam pengajaran dan pembelajaran, Filipenko (2016: 4). Shoimin (2014) mengungkapkan bahwa PBL dapat melatih dan mengembangkan kemampuan untuk menyelesaikan masalah yang berdasarkan pada masalah dari kehidupan aktual siswa, untuk merangsang kemampuan berpikir tingkat tinggi.

Problem Based Learning menghendaki siswa agar aktif untuk memecahkan masalah yang sedang dihadapi olehnya. oleh karena itu, dapat ditarik kesimpulan dari beberapa pendapat di bahwa PBL atau problem based learning merupakan pembelajaran yang menyajikan masalah sehari-hari dengan tujuan untuk menciptakan proses berfikir dan keterampilan memecahkan masalah siswa selama pembelajaran.

Setiap masalah tentu menuntut adanya suatu solusi. Untuk mencapai solusi tersebut diperlukan adanya proses pemecahan masalah. menurut Engel (1998: 1) Pemecahan masalah hanya bisa dipelajari dengan memecahkan masalah, tetapi itu harus didukung oleh strategi yang disediakan oleh pelatih, atau oleh para ahli seperti strategi yang telah disediakan oleh Polya dengan melakukan langkah-langkahnya secara benar maka dapat melatih kemampuan pemecahan masalahnya.

Pemecahan masalah merupakan bagian utama dalam aktivitas pembelajaran matematika. Kemampuan pemecahan masalah merupakan hal yang harus mendapatkan perhatian, mengingat perannya yang sangat strategis dalam mengembangkan potensial intelektual anak. Menurut Shadiq (2009: 14) pemecahan masalah merupakan kompetensi stategis yang 
ditunjukan siswa dalam memahami, memilih pendekatan dan strategi pemecahan masalah, dan menyelesaikan model untuk menyelesaikan masalah.

Kemampuan pemecahan masalah matematika Liljedahl (2019) Pemecahan masalah matematika telah lama dilihat sebagai aspek penting dari matematika, pengajaran matematika, dan pembelajaran matematika. Pemecahan masalah matematika diterapkan pada semua kurikulum matematika diseluruh dunia, untuk mengajarkan pemecahan masalah serta pengajaran matematika melalui pemecahan masalah matematika, contohnya pemecahan masalah untuk menghitung besarnya volume maka untuk memecahkannya harus menggunakan prosedur-prosedur yang benar. Berdasarkan pengertian-pengertian tersebut disimpulkan pengertian kemampuan pemecahan masalah metematika adalah ketrampilan siswa dalam menerapkan pengetahuan matematika yang diperoleh dalam upaya mengatasi suatu masalah. Menurut Polya (1973), terdapat empat tahap penting dalam pemechan masalah yaitu: understanding the problem, devising a plan, carrying out the plan, dan looking back.

Olivier (2018) Self-efficacy adalah salah satu faktor kunci untuk meraih prestasi akademik siswa, self-efficacy siswa juga sebagai predikator penting dari keberhasilan dalam tugas akademik dan evaluasi. Selain itu selfefficacy siswa merupakan keyakinan bahwa siswa memiliki kemampuan mereka untuk mengorganisasikan dan melaksanakan tindakan yang diperlukan untuk mempelajari, menguasai tugas dan penugasan pada tingkat yang memuaskan.

Bandura (1997) mengartikan self-efficacy sebagai keyakinan seseorang yang memiliki kemampuan untuk menyelesaikan tugas tertentu dengan sukses dan kepercayaan ini berkaitan dengan kinerja dan ketekunan dalam berbagai usaha. self-efficacy merupakan keyakinan seseorang terhadap kemampuannya untuk sukses dalam melakukan aktifitas tertentu dalam Jainuri (2017). Self-efficacy yang baik dapat membantu seseorang dalam menentukan pilihan, usaha untuk maju, kegigihan, ketekunan yang mereka tunjukan dalam menghadapi kesulitan, dan derajat kecemasan atau ketenangan yang mereka alami saat mereka mempertahankan keputusan-keputusan yang mencangkup kehidupan mereka. Selain itu menurut Villavicencio (2015) Self-efficacy adalah evaluasi individu bahwa ia memiliki kemampuan kinerja yang spesifik pada jenis tugas tertentu.

Berdasarkan pengertian yang telah dipaparkan di atas, dapat disimpulkan bahwa self-efficacy adalah keyakinan individu untuk melakukan tugas tertentu dan berhasil dan secara spesifik. Dan keyakinan yang dimilikinya, seorang siswa dapat mengatasi dan menyelesaikan suatu tugas yang mungkin dapat membuatnya malu gagal atau stres sehingga mencapai tujuan yang diharapkan. Tugas tersebut dapat berupa PR, Mengerjakan buku paket, LKS dan soal-soal yang diberikan oleh guru.

Dimensi self-efficacy menurut Bandura (1977) adalah (1) Level/ Magnitude berkaitan dengan derajat kesulitan tugas yang dihadapi dimana seseorang merasa mampu atau tidak untuk melakukannya; (2) Strenght merupakan kekuatannya keyakinan yang berkaitan dengan ketahanan dan keuletan individu dalam pemenuhan tugasnya; dan (3) Generality yang berkaitan dengan keyakinan seseorang akan kemampuannya melaksanakan tugas di berbagai aktivitas dan situasi tertentu. Aktivitas dan situasi yang bervariasi menuntut Apakah seseorang merasa yakin atau tidak yakin atas kemampuannya dalam melaksanakan tugas.

Sebagai kontrolnya menggunakan Model Pembelajaran langsung adalah suatu pengajaran yang bersifat teacher center. Menurut Arends dalam Lestari dan Yudhanegara (2015) bahwa pembelajaran langsung merupakan suatu model pembelajaran yang bertujuan untuk 
membantu siswa mempelajari keterampilan dasar dan pengetahuan yang dapat diajarkan secara bertahap selangkah demi selangkah. Pembelajaran langsung dilandasi oleh teori belajar behavioristik yang menitikberatkan pada penguasaan konsep dan perubahan perilaku sebagai hasil belajar yang dapat diobservasi. Menurut Brace dan Weli dalam Lestari dan Yudhanegara (2015) mengemukakan lima fase atau tahapan pembelajaran dalam pembelajaran orientasi, presentasi atau demonstrasi, latihan terstruktur, latihan terbimbing, dan latihan mandiri.

\section{Metode Penelitian}

Dalam penelitian ini desain penelitian yang dipakai adalah posttest-only control desain yang terdiri dari dua kelompok subjek penelitian yaitu kelompok ekperimen (E) dan kelompok kontrol (K). Kelompok eksperimen diberi perlakuan dengan menggunakan problem based learning dan kelompok kontrol tidak diberi perlakuan yang hanya menggunakan pembelajaran langsung. Adapun desain penelitian ini sebagai berikut:

Tabel 1. Desain Penelitian

\begin{tabular}{lll}
\hline Kelompok & Perlakuan & Post test \\
\hline E & $\mathrm{X}$ & $\mathrm{YZ}$ \\
$\mathrm{K}$ & - & $\mathrm{YZ}$ \\
\hline
\end{tabular}

Keterangan:

$\mathrm{E}=$ kelompok kelas eksperimen.

$\mathrm{K}=$ kelompok kelas kontrol.

$\mathrm{X}=$ perlakuan (treatment) menggunakan problem based learning.

$\mathrm{Y}=$ pemberian post test kemampuan pemecahan masalah.

$\mathrm{Z}=$ pemberian angket self-efficacy.

Jenis instrumen yang digunakan dalam penelitian ini adalah berupa tes bentuk uraian yang sesuai dengan indikator pemecahan masalah untuk mengukur kemampuan pemecahan masalah. metode tes digunakan untuk memperoleh data nilai siswa setelah diberi perlakuan pada kelas eksperimen maupun kelas kontrol berupa post test. data yang diperoleh dari postes kedua kelas tersebut nantinya akan dibandingkan untuk melihat kemampuan mana yang lebih baik.

Angket digunakan untuk mendapatkan gambaran mengenai self-efficacy siswa, menggali informasi mengenai self-efficacy siswa, angket self-efficacy disusun berdasarkan indicatorindikator variabel yang merupakan ciri-ciri perilaku yang hendak diteliti dan berisi pernyataan-pernyataan yang harus dijawab dengan pilihan yang paling sesuai dengan individu tersebut. Bentuk skala yang digunakan dalam penelitian adalah skala linkert, dengan empat alternatif pilihan jawaban yang terdiri dari kelompok item favourable dan unfavourable yang bergerak mulai dari: SS(Selalu), S(Sering), J(Jarang), TP(Tidak Pernah).

Lembar observasi digunakan untuk penelitian aktivitas guru dan siswa dalam proses pembelajaran di kelas. lembar observasi dibuat berdasarkan langkah-langkah pada rencana pelaksanaan pembelajaran dan nantinya akan menjadi pendukung. pengisian lembar observasi ini dengan cara memberikan tanda ceklis $(\sqrt{ })$ pada kolom "Ya" atau "Tidak" kolom yang diisi "Ya" jika aspek yang diamati dilakukan oleh guru maupun siswa, sedangkan kolom "Tidak" diisi jika aspek yang diamati tidak dilakukan oleh guru maupun siswa. 
Instrumen dokumentasi digunakan oleh peneliti untuk mendukung keadaan nyata selama penelitian dokumentasi dalam penelitian ini meliputi kegiatan selama proses pembelajaran dan hasil pekerjaan siswa.

Validitas merupakan derajat ketepatan antara data yang terjadi pada objek penelitian dengan daya yang dapat dilaporkan oleh peneliti. Instrumen dikatakan valid apabila instrumen tersebut dapat mengukur apa yang seharusnya diukur (Sugiyono, 2015: 173). Adapun teknik yang digunakan untuk mengetahui valid atau tidaknya suatu instrumen dengan korelasi product moment pearson (Arikunto, 2012: 87) dengan mengkorelasikan antara skor yang didapat siswa dengan skor total. Rumus korelasi product moment pearson.

Agar memudahkan proses pengelolaan validasi soal maka peneliti menggunakan bantuan program SPSS for Windows 20.0 dengan uji correlate bivariate. Penarikan kesimpulan berdasarkan analisis dengan menggunakan SPSS 20.0 soal dikatakan valid jika sig. $\leq \alpha$ dengan $\alpha=0,05$. (Siregar, 2015: 48).

Reliabilitas adalah konsistensi dari serangkaian alat ukur. Pengujian reliabilitas dengan Internal consistency yaitu dengan mengujicobakan instrumen, untuk kemudian dianalisis dengan teknik tertentu (Sugiyono, 2015: 190). Suatu alat ukur dikatakan reliabel bila alat ukur itu dalam mengukur suatu gejala pada waktu yang berlainan senantiasa menunjukkan hasil yang sama. Teknik yang digunakan untuk menguji reliabilitas dari instrumen pada penelitian ini dengan menggunakan rumus alpha cronbach (Siregar, 2015: 58).

Agar memudahkan proses pengelolaan validasi soal maka peneliti menggunakan bantuan program SPSS for Windows 20.0 dengan uji reliability analysis untuk membantu perhitungan dengan analisis reliabilitas soal. Nilai koefisien reliabilitas atau alpha cronbach's diatas 0,7 sudah cukup baik (Janti, 2014: 2), dan Instrumen dapat dikatakan reliabel.

Untuk menguji data hasil tes kemampuan pemecahan masalah dan angket self efikasi pada kelas eksperimen dan kelas kontrol. Apabila ketentuan untuk uji prasyarat pada uji normalitas terpenuhi yaitu berdistribusi normal maka analisis data menggunakan statistik parametrik sehingga pengujian hipotesis menggunakan uji-t karena membandingkan selisih dua sampel bebas.

Namun, dalam penelitian ini, peneliti menggunakan bantuan program SPSS 20.0. program SPSS 20.0 ini digunakan untuk mempermudah perhitungan hasil tes. Peneliti menggunakan uji independent sample test yang terdapat dalam proram SPSS 20.0 untuk melakukan pengujian hipotesis.

\section{Hasil dan Pembahasan}

Setelah peneliti menentukan kelas eksperimen dan kelas kontrol melalui cluster random sampling, maka penelitian dapat dilakukan. Dapat diketahui bahwa telah diperoleh 2 kelas sampel yaitu kelas eksperimen yang menggunakan problem based learning dan kelas kontrol yang menggunakan pembelajaran langsung. Kedua kelas mendapatkan materi yang sama yaitu bangun ruang sisi datar. Setiap kelas mendapatkan pertemuan dalam pembelajaran sebanyak 4 kali dengan rincian 2 x 40 menit sebanyak 2 kali dan 3 x 40 menit sebanyak 2 kali setiap proses pembelajaran dilakukan penelitian untuk memperoleh data aktivitas guru dan siswa.

Proses pembelajaran kelas eksperimen, siswa diajarkan menggunakan problem Based Learning dan di dalam problem based learning terdapat 5 tahapan yaitu :

a. Orientasi siswa pada masalah. guru menjelaskan tujuan pembelajaran, menjelaskan teknik yang dibutuhkan, memotivasi siswa agar terlibat aktif dalam pemecahan masalah yang 
dipilih, pada kegiatan ini siswa dituntut aktif dalam pembelajaran serta untuk mengemukakan pendapatnya.

b. Mengorganisasikan siswa untuk belajar guru membentuk kelompok belajar siswa dan membagikan masalah serta membantu siswa mendefinisikan serta mengorganisasikan tugas belajar yang berhubungan dengan masalah tersebut. pada kegiatan ini siswa berdiskusi dengan anggota kelompok masing-masing guna mendapatkan jawaban dari permasalahan tersebut.

c. Membimbing penyelidikan individu dan kelompok siswa didorong untuk mengumpulkan informasi yang sesuai melaksanakan eksperimen untuk mendapatkan penjelasan dan pemecahan masalahnya. pada kegiatan ini siswa didampingi oleh guru jika siswa merasa kesulitan maka guru memancing pemikiran siswa agar siswa dapat semakin merujuk ke jawaban.

d. Mengembangkan dan menyajikan hasil karya siswa dibantu guru merencanakan dan menyiapkan karya yang sesuai seperti laporan hasil diskusi kelompok. pada kegiatan ini siswa mempersiapkan dan mengungkapkan pendapatnya kepada kelompok lain.

e. Menganalisis dan mengevaluasi proses pemecahan masalah salah satu kelompok diminta mempresentasikan hasil kerja kemudian secara bersama-sama melakukan refleksi dan evaluasi terhadap proses proses yang telah digunakan, kemudian setelah itu siswa mengevaluasi jawabannya.

Pembelajaran langsung merupakan pembelajaran yang berpusat pada guru, dimana guru menyampaikan materi sedangkan siswa hanya menerima materi tanpa terlibat aktif. Terdapat lima tahapan pembelajaran langsung yaitu:

a. Orientasi, pada fase ini guru memberikan kerangka pembelajaran dan orientasi terhadap materi pembelajaran kegiatan yang digunakan, pada fase ini meliputi kegiatan pendahuluan menyampaikan tujuan pembelajaran dan memotivasi siswa. Siswa mendengarkan guru yang sedang menyampaikan tujuan pembelajaran.

b. Presentasi atau demonstrasi pada fase ini guru menyajikan materi pembelajaran baik, berupa pemecahan masalah maupun keterampilan kegiatan pada fase ini meliputi penyajian materi pemberian contoh pemecahan masalah atau peragaan keterampilan. Pada tahapan ini siswa memperhatikan guru menerangkan materi yang sedang disampaikan.

c. Latihan terstruktur, pada fase ini guru melakukan penguatan dengan memberikan contoh pengerjaan latihan soal yang terstruktur, pada kegiatan ini siswa memperhatikan guru yang sedang menyajikan contoh persoalan yang berkaitan dengan materi yang sedang diajarkan beserta jawabannya.

d. Latihan terbimbing, pada fase ini guru memberikan lembar kegiatan kelompok dan melaksanakan bimbingan dengan memonitor proses pengerjaan lembar kegiatan kelompok yang dilakukan siswa. Guru mengelilingi kelas dan memeriksa pekerjaan siswa serta mengoreksi jika siswa melakukan kesalahan dalam setiap pengerjaannya, pada kegiatan ini siswa mengerjakan latihan soal yang diberikan oleh guru dan setelah itu siswa dicek jawabannya jika siswa salah dalam menjawab lalu guru memiliki jawaban yang benar.

e. Latihan mandiri pada fase ini guru memberikan kesempatan kepada siswa untuk terus berlatih baik pemecahan masalah maupun keterampilan secara mandiri dengan memberikan tugas-tugas yang dikerjakan secara individual pada kegiatan ini siswa dilatih untuk mandiri mengerjakan soal agar terbiasa dengan soal-soal tersebut. 
Data utama pada penelitian penelitian ini diperoleh dari hasil post test kemampuan pemecahan masalah dan angket self-efficacy siswa. Soal post tes dan pernyataan angket sudah diujicobakan terlebih dahulu sehingga diperoleh soal dan pernyataan yang seluruhnya valid dan reliabel. Selanjutnya, soal dan pernyataan dapat digunakan dalam post test dan angket pada kelas eksperimen dan kelas kontrol. Hasil perbandingan post test secara keseluruhan diuraikan sebagai berikut.

Tabel 2. Data Hasil Post Test Kelas Eksperimen dan Kelas Kontrol

\begin{tabular}{ccccc}
\hline & N & Minimum & Maximum & Mean \\
\hline Nilai_kelas_kontrol & 31 & 35,00 & 95,00 & 75,0806 \\
Nilai_kelas_eksperimen & 33 & 60,00 & 100,00 & 82,8788 \\
Valid N & 31 & & & \\
\hline
\end{tabular}

Berdasarkan gambar terlihat bahwa nilai rata-rata kelas eksperimen lebih besar daripada nilai rata-rata kelas kontrol. kelas eksperimen mendapat nilai ratarata untuk kemampuan pemecahan masalah yaitu 82,8788 sedangkan kelas kontrol mendapatkan nilai rata-rata untuk kemampuan pemecahan masalah yaitu 75,0806. Selisih nilai rata-rata kedua kelas yaitu 7,79. Nilai terendah dan nilai tertinggi pada kelas eksperimen juga lebih besar dari pada nilai terendah dan nilai tertinggi pada kelas kontrol.

Tabel 3. Data Hasil Angket Kelas Eksperimen dan Kelas Kontrol

\begin{tabular}{llllc}
\hline & N & Minimum & Maximum & Mean \\
\hline Nilai_kelas_kontrol & 31 & 46,05 & 68,42 & 57,9372 \\
Nilai_kelas_eksperimen & 33 & 53,95 & 69,74 & 60,4864 \\
Valid N & 31 & & & \\
\hline
\end{tabular}

Berdasarkan gambar terlihat bahwa nilai rata-rata kelas eksperimen lebih besar dari pada nilai rata-rata kelas kontrol. kelas eksperimen dan mendapatkan nilai rata-rata untuk self-efficacy yaitu 60,4864 sedangkan kelas kontrol mendapatkan nilai rata-rata untuk self-efficacy yaitu 57,9372 selisih nilai rata-rata ke dua kelas yaitu 2,5496. Nilai terendah dan nilai tertinggi untuk self-efficacy pada kelas eksperimen juga lebih besar daripada nilai terendah dan nilai tertinggi kelas kontrol.

Hasil analisis uji hipotesis pada kemampuan pemecahan masalah dapat diperoleh bahwa kemampuan pemecahan masalah siswa yang mengikuti problem based learning lebih baik daripada siswa yang mengikuti pelajaran langsung. Hal tersebut ditunjukkan dengan hasil perhitungan dengan bantuan program SPSS 20.0 independent sample test diperoleh nilai sig $=$ 0,02 dan $\alpha=0,05$.

Hasil uji hipotesis pada self-efficacy diperoleh bahwa capaian self-efficacy siswa yang mengikuti problem based learning lebih baik daripada siswa yang mengikuti pembelajaran langsung. Hal tersebut ditunjukkan dengan hasil perhitungan dengan bantuan program SPSS 20.0 independent sample test diperoleh nilai $\operatorname{sig}=0,038$ dan $\alpha=0,05$. 
Hal diatas tidak terjadi secara kebetulan melainkan adanya perbedaan tahap-tahap pembelajaran antara kelas eksperimen dan kelas kontrol proses pembelajaran yang berlangsung pada kelas eksperimen pada umumnya akan menciptakan siswa agar bisa memecahkan masalah yang ada dengan sendirinya dengan tuntunan oleh guru, agar tidak salah arah nantinya nya. Berdasarkan lembar observasi guru dan siswa juga menunjukkan bahwa kelas yang mengikuti problem based learning lebih terlihat aktif dan bekerja sama satu sama lain dalam menyelesaikan masalah yang berhubungan dengan kemampuan pemecahan masalah pada lembar LKK yang diberikan.

Siswa juga diberikan kesempatan lebih banyak untuk mengembangkan pikirannya sendiri ke dalam LKK yang sudah disediakan sehingga mampu mengoptimalkan kemampuan pemecahan masalah yang dimiliki siswa. Pengelompokan sesuai dengan aturan yang sudah ditentukan dengan tujuan agar siswa yang kemampuan tinggi dapat membantu siswa yang berkemampuan rendah sehingga terjalin interaksi satu sama lain yang dapat membantu siswa yang kurang paham menjadi paham. Oleh karena itu, siswa lebih bersemangat dalam mengerjakan LKK setelah siswa menyelesaikan LKK siswa diberikan tugas terkait kemampuan pemecahan masalah pada materi bangun ruang sisi datar kemudian dikumpulkan untuk mengetahui ke konsistenan siswa pada tugas yang diberikan tugas tersebut bertujuan untuk mengetahui sejauh mana siswa dalam memahami materi yang sudah diberikan secara individu.

Berbeda dengan kelas yang mengikuti pembelajaran langsung proses pembelajaran yang berlangsung membuat siswa menjadi lebih pasif, karena siswa hanya menyalin apa yang ada di papan tulis dan lebih mengutamakan hasil akhir yang tepat tanpa mengetahui prosesnya saat guru menjelaskan pada pembelajaran ini siswa juga kurang diberikan kesempatan untuk menuangkan pikirannya secara individu karena terpaku dengan anggota kelompok siswa hanya mengandalkan anggota kelompok yang dianggap memiliki kemampuan tinggi akibatnya siswa tidak dapat mengoptimalkan kemampuan pemecahan masalah.

\section{Simpulan}

Berdasarkan uraian pembahasan diatas dapat disimpulkan bahwa : 1.capaian kemampuan pemecahan masalah siswa yang mengikuti Problem based learning lebih baik dari pada kemampuan pemecahan masalah siswa yang mengikuti pembelajaran langsung. 2.capaian self-efficacy siswa yang mengikuti problem based learning lebih baik dari pada self-efficacy siswa yang mengikuti pembelajaran langsung dengan demikian dapat disimpulkan bahwa problem based learning berpengaruh terhadap kemampuan pemecahan masalah dan selfefficacy siswa.

\section{Daftar Pustaka}

Akinaglu O \& Ruhan Ozkardes Tandogan, R. (2007). The effects of problem based active learning of student' academic achievement, attitude and concept learning. Eurasia Journal of Mathematics, Science \& Technology Education, 3 (1): 71-81

Arikunto, S. (2012). Dasar-Dasar Evaluasi Pendidikan Edisi 2. Jakarta : Bumi Aksara.

Bandura, A. (1977). Self-efficacy : Toward a unifying theory of behavioral change. Psychological review 84 (2), 191.

Engel, Arthur. (1998). Problem-solving strategies. Spinger.

Filipenko, Margot. (2016). Problem-Based Learning in Teacher Education. Spinger. 
Handayani, D. (2017). Pengaruh Model Problem Based Learning Terhadap Kemampuan Pemecahan Masalah Matematis Siswa di Kelas VIII MTs. S ALWashliyah Tahun Ajaran 2016/2017. Skripsi; Universitas Islam Negeri Sumatra Utara.

Janti, S. (2014). Analisis Validitas Dan Reliabilitas Dengan Skala Likert Terhadap Pengembangan Si/Ti Dalam Penentuan Pengambilan Keputusan Penerapan Strategic Planning Pada Industri Garmen. SNAST.

Jainuri, M. (2017). Eksperimentasi Model Sinetik Terhadap Kemampuan Pemecahan Masalah Matematis Dan Self-efficacy Siswa. EDUMATICA/Jurnal Pendidikan Matematika, 7 (02), 51-60.

Kek, M.Y.C.A dan Huijser,Henk. (2017). Problem-based Learning into The Future. Springer.

Lestari, K.E. Dan Yudhanegara, M.R. (2015). Penelitian Pendidikan Matematika. Bandung : PT Refika Aditama.

Liljedahl, peter. (2019). Mathematical Problem Solving Current Themes, Trends, and Research. Springer.

Moma, L. (2014). Peningkatan Self-efficacy Matematis Siswa SMP Melalui Pembelajaran Generatif. Jurnal Cakrawala Pendidikan, 3 (3).

Maddux. J.E. (1995). Self-efficacy, Adaptation and Adjustment: Theory, Research, and Application. Springer Science.

NCTM-National Council of Teacher of Mathematics. (2000). Prinsciples and standards for school mathematics. VA: NCTM.

Polya. (1973). How To Solve It? A New Aspect Of Mathematical Method (2nd Edition). New Jersey : Princeton University Press.

Shadiq, Fadjar. (2009). Kemahiran Matematika. Yogyakarta : P4TKM.

Siregar, S.(2015). Metode Penelitian Kuantitatif dilengkapi dengan Perbandingan Perhitungan Manual Dan SPSS. Jakarta : Prenada Media Grup.

Shoimin, A. (2014). 65 Model Pembelajaran Inovatif Dalam Kurikulum 2013. Yogyakarta : Ar-Ruzz Media.

Sugiyono. (2015). Metode Penelitian Kuantitatif Kualitatif dan R\&D. Bandung : Alfabeta.

Villavicencio F.T , Bernardo A.B.I (2015). Beyond Math Anxiety: Positive Emotions Predict Mathematics Achievement, Self-Regulation, and Self-efficacy. AsiaPacific Edu Res

Wardani, S. (2008). Analisis SI dan SKL Mata Pelajaran Matematika SMP/MTs untuk Optimalisasi Tujuan Mata Pelajaran Matematika. Yogyakarta : P4TKM.

Wiratmaja, Sadia, Suastra. (2014). Pengaruh Model Pembelajaran Berbasis Masalah Terhadap Self-efficacy dan Emotional Intelligence Siswa SMA. e-Journal Program Pascasarjana Universitas Pendidikan Ganesha Program Studi IPA (Volume 4 Tahun 2014). 